Kjersti Flфttum*

\title{
Teksttype og polyfoni
}

\begin{abstract}
There is a general scepticism as to definitions of text types based on determined linguistic criteria. The subject of this article is to show how it is possible to strengthen the linguistic basis of text typologies. After a description of the evolution of text typology from Werlich (1976) via van Dijk (1980) to Adam (1992), linguistic polyphony is presented as a contribution to a linguistic foundation of Adamís prototypical typology. It is shown how the polyphonic structure can describe, make explicit and explain typological text features.
\end{abstract}

\section{Innledning}

Kan en tekst, i sin vanlige betydning av innholdsmessig helhet, bestemmes som et eksempel på en type, ved hjelp av utvalgte lingvistiske kriterier? Dette er et av de viktigste spørsmålene innenfor studier om teksttypologi. Svarene vil variere alt etter teoretisk retning. Likevel kan man vel si generelt at skepsisen er stor når det gjelder oppfatningen av at tilstedeværelsen av bestemte språklige fenomen kan bestemme en teksttype. Ikke desto mindre er språklige kriterier for teksttyper stadig et viktig studieobjekt.

Utgangspunktet for denne artikkelen er den skepsis som er nevnt ovenfor. Men hovedproblemstillingen er mer konstruktiv. Den vil dreie seg om på hvilken måte man eventuelt kan styrke den språklige forankringen i lingvistiske teksttypologier. Det er nemlig slik at uansett hvordan man besvarer spørsmålet formulert innledningsvis, må man i mange sammenhenger hvor man arbeider med tekst, forholde seg til begrepet teksttype. Likeledes er spørsmålet, etter min oppfatning, teoretisk svært interessant.

Mitt mål er å vise at et bidrag i bestrebelsen på å forankre teksttypologisering språklig, kan være den lingvistiske versjonen av polyfoni-

* Kjersti Flфttum

Romansk institutt, seksjon for fransk

Universitetet $i$ Bergen

N-5007 Bergen

Hermes, Journal of Linguistics no. 20 - 1998 
teorien, slik den er utviklet av Oswald Ducrot (1984) og Henning Nølke (1989 og 1994). Jeg ønsker å bygge videre på noen av de refleksjoner om polyfoni relatert til teksttypologi som jeg har presentert i tidligere arbeider (Fløttum under utgivelse a, b, c), og vise noen av polyfoniteoriens fortrinn i denne sammenheng.

En viktig presisering er på sin plass: Begrepet teksttype blir i denne artikkel anvendt og diskutert i forhold til de sammenhenger hvor det brukes av språkvitere som Egon Werlich (1976), Teun A. van Dijk (1980) og Jean-Michel Adam (1992). Grovt sett kan man si at det dreier seg om lingvistiske tilnærmingsmåter til teksttypologisering, hvor kriteriene som danner basis for typologiseringen, er dem man gjerne kaller tekstinterne. Disse skiller seg fra mer sosio-kulturelle eller sosio-profesjonelle tilnærminger, hvor studieobjektet først og fremst er tekstgenrer med tekstens kommunikative formål som det viktigste klassifiseringskriterium (som for eksempel i arbeidene til John M. Swales 1990 og Vijay K. Bhatia 1993). I denne sammenheng viser jeg til Finn Frandsens artikkel om kategoriseringsmodeller innen tekstgenreproblematikken (Frandsen 1995) og til Winni Johansens artikkel som blant annet inneholder en kritisk gjennomgang av Bhatias modell (Johansen 1995).

For å kunne si noe fornuftig om polyfoniteoriens eventuelle bidrag, vil jeg studere den i forhold til en allerede etablert typologi. Denne skal være Adams sekvenstypologi (Adam 1992), som representerer et sentralt referansepunkt i teksttypestudier og som etterhvert er blitt utprøvd i forskjellige sammenhenger. For å gi et best mulig bilde av Adams modell vil jeg se på hvordan den forholder seg til tidligere fors $\varnothing \mathrm{k}$ på teksttypologisering. Til dette formål har jeg valgt ut og begrenset meg til de to modellene i henholdsvis Werlich (1976) og van Dijk (1980).

\section{Utviklingen fra Werlich (1976) via van Dijk (1980) til Adam (1992)}

Werlichs (1976) utgangspunkt er mer en setningstypologi enn en teksttypologi. Gjennom sin utvikling av en setningstypologi ønsker han å skape et fundament for en tekstgrammatikk, som også skal ha sin basis i en teksttypologi. I sin grammatikk ser han på setningen og dens elementer som en enhet av lavere orden innenfor spesifikke typer av tekst eller innenfor andre enheter av høyere orden enn setningen, som 
for eksempel avsnittet (se Werlich 1976: 11). Werlich begrunner nødvendigheten av en tekstgrammatikk, som både skal inneholde og overskride en setningsgrammatikk, med at setninger vanligvis opptrer som elementer som er avhengige av teksten de forekommer i. Han legger vekt på at språkbrukere kan antas å følge regler i setningsproduksjon som tjener til å skape helhetlig tekst.

Werlich hevder at tekster kan klassifiseres med basis i det han kaller dominerende kontekstuelt fokus («dominant contextual focus»), (op. cit.: 19). Han opererer med fem slike:

a) fokus på spatial kontekst som gir deskriptive tekster,

b) fokus på temporal kontekst som gir narrative tekster,

c) fokus på dekomposisjon eller komposisjon som gir ekspositive (eller fremstillende) tekster,

d) fokus på relasjoner mellom fenomener som gir argumentative tekster, og

e) fokus på fremtidig opptreden som gir instruktive tekster.

Denne inndelingen i fem basistyper danner grunnlaget for all videre beskrivelse i Werlichs tekstgrammatikk. Han mener også at de har en kognitiv begrunnelse: De svarer til fem basale kognitive kategoriseringsprosesser (henholdsvis «perception in space», «perception in time», «comprehension», «judging», «planning»). Uten å gå dypere inn i hans begrunnelser, vil jeg nevne hans understreking av gyldigheten til de fem teksttypene han kommer frem til:

"The dominant contextual foci distinguished (...) point to five basic text types to which all texts can be assigned, including those in which several foci are mixed» (op.cit.:21).

Det er grunn til å merke seg to forhold i hans kraftige hypotese: Inndelingen bygger på dominans, og den gjelder for alle tekster.

I følge Werlich kan en tekstbase for hver av de fem typene formuleres i en enkel typesetning (op.cit.: 39-40):

a) For deskriptiv tekst: «a simple phenomenon-registering sentence»: Thousands of glasses were on the tables.

b) For narrativ tekst: «a simple (non-continuous) action-recording sentence»:

The passengers landed in New york in the middle of the night. 
c) For ekspositiv tekst (to undertyper):

- «a simple phenomenon-identifying sentence»:

One part of the brain is the cortex or rind.

- «a simple phenomenon-linking sentence»:

The brain has ten million neurones.

d) For argumentativ tekst: «a negated quality-attributing sentence»: The obsession with durability in the arts is not permanent.

e) For instruktiv tekst: «an action-demanding sentence»:

Stop! Don't move!

En konkret tekst, som en bestemt teksttype manifesterer seg i, vil da være dominert av slike basissetninger og deres varianter. For konkrete tekster, bruker Werlich videre begrepene tekstform og tekstformvarianter som betegnelser på konvensjonelle genre, som for eksempel «commentary» (tekstform) og «leading article» (tekstformvariant). Disse blir beskrevet i detalj i henhold til faktorene point of view, composition, variety.

Hvordan skal man vurdere Werlichs typologi? Det kan i alle fall sies at det er ambisiøst og modig av Werlich å fremsette en så vidtrekkende hypotese om teksttyper. Typologien er klart språklig forankret, men man savner en mer utførlig begrunnelse for typesetningenes lingvistiske utforming, for eksempel for faktoren «non-continuous» i narrativer, for «negated» $\mathrm{i}$ argumentativer og for oppsettet av to setninger (som er interessante både syntaktisk og semantisk) i instruktiver.

Når det gjelder antall typer, og betegnelsene på disse, er det et emne som stadig blir diskutert innen teksttypologi. Her er Werlich blitt et viktig referansepunkt.

Når det gjelder typologiens basis i enkle setningstyper, er det en hypotese som er blitt sterkt imøtegått fra forskjellige hold (blant annet av Adam 1992). For det første fremsettes gjerne autentiske teksters heterogene karakter som en faktor som avviser hypotesen om basissetninger. For det andre blir Werlichs kategorier betraktet som ikke tilstrekkelig distinktive til å skille mellom de forskjellige typer. Når man skal bestemme en konkret tekst som tilhørende en bestemt type, får man heller ingen hjelp fra dominans-begrepet siden basissetningene ikke er klart nok definerte.

I enkelte sammenhenger innenfor teksttypologistudier, er det blitt lagt større vekt på teksters komposisjonelle struktur. Teun A. van Dijk 
(1980) har blant annet vært viktig for utviklingen av begrepet superstruktur. I følge hans teori, organiserer en teksts superstruktur tekstens innholdselementer i en kompositorisk formell helhet. Innholdselementene tillegges bestemte funksjoner (gjerne kalt retoriske funksjoner (op.cit.: 107)), som definerer den funksjonelle relasjon de har til hverandre. Når van Dijk snakker om superstruktur, mener han i hovedsak konvensjonelle funksjoner som etableres innenfor bestemte skjemaer (schemata (op.cit.: 108)). En superstruktur kan på denne måten betraktes som en struktur som representerer en teksts globale form (i motsetning til makrostrukturen som representerer tekstens globale innhold) og som organiserer tekstens globale mening.

En superstruktur, ifølge van Dijks fremstilling (1980), består av funksjonelle kategorier. Et sett regler er nødvendig for å spesifisere hvilke kategorier som kan kombineres med hverandre og kategorienes rekkefølge. Disse kategoriene og reglene skal være sosiokulturelt akseptert av språkbrukere i et gitt språksamfunn. van Dijk antyder at den narrative strukturen kanskje er det mest karakteristiske eksempel på en slik konvensjonell, skjematisk superstruktur (op.cit.: 109), slik den for eksempel uttrykkes i en fortelling («story»). Han nevner den argumentative superstruktur, med kategorier som premisser og konklusjon, som et annet velkjent eksempel.

Van Dijk presiserer at en superstruktur inneholder form-kategorier som kan bli fylt med forskjellig innhold. Men han hevder at slike former representerer visse restriksjoner for innholdet, som for eksempel at ikke enhver konklusjon kan følge hvilke som helst premisser.

Det er også viktig for van Dijk å betrakte superstrukturer som bestående av hierarkisk ordnede kategorier (op.cit.: 127). Slik har superstrukturen stor innflytelse på den innholdsmessige makrostrukturen: Superstrukturen bestemmer hvilken informasjon som er viktig eller relevant for teksten som helhet. Følgelig er det slik at superstrukturen ikke bare organiserer makrostrukturen, men, som nevnt ovenfor, den setter også opp visse restriksjoner for tekstens innhold.

Mens Werlich foreslår sin modell som generell, tar van Dijk utgangspunkt i eksempler for å vise superstrukturbegrepets anvendelsesområde. Van Dijk er mer forsiktig enn Werlich i den forstand at han ikke påstår at enhver tekst har en gitt superstruktur. Selv om visse superstrukturskjemaer kan gi velbegrunnede indikasjoner på teksttype (op. cit.: 110), kan ikke en generell teksttypologi baseres kun på super- 
strukturbegrepet. Også pragmatiske og sosio-kulturelle faktorer må tas $i$ betraktning.

Når van Dijk går inn på bestemte superstrukturer, foreslår han fïe til fem funksjonelle basiskategorier (eller metakategorier) som kan gjelde generelt: introduction, problem, solution, conclusion og eventuelt evaluation. Disse får sine spesifikke utfyllinger i forskjellige superstrukturer. Van Dijk beskriver fire slike: narrativ, argumentativ, vitenskapelig fremstilling, avisartikkel (i denne siste innrømmer forfatteren at «the schematic structure is rather loose» (op.cit.: 121)).

I sin konklusjon uttrykker van Dijk skepsis til en rent lingvistisk basis for superstrukturen fordi de eventuelle formelle bånd mellom superstrukturer og grammatiske strukturer ikke er kjent. Og selv om han har påpekt at superstrukturskjemaer og kategorier representerer visse restriksjoner, så er ikke de aktuelle restriksjonene presist formulert (det eksakte forhold mellom makro- og superstruktur). Ikke desto mindre, sier van Dijk, er superstrukturens mulige overflatestrukturer og mikrostrukturelle manifestasjoner lingvistisk interessante (op.cit.: 130), med andre ord hvordan hver enkelt kategori kan være formet eller språklig markert.

Hvordan er så superstrukturbegrepet blitt vurdert? Begrepet har vært viktig og synes fortsatt å være i bruk innenfor tekstlingvistiske studier. Imidlertid har det også måttet tåle mye kritikk, blant annet av Adam (1992), som avviser at hele tekster kan tilpasses ett superstrukturskjema. I en viss forstand, kan Adams kritikk av van Dijk synes noe uberettiget. Hvis vi går i dypden i van Dijks fremstilling om superstrukturer, ser vi at han utviser stor forsiktighet til en generell anvendelse av sitt eget superstrukturbegrep. Likeledes åpner han tydelig for at en struktur kan være iblandet en annen (se for eksempel hans beskrivelse av en psykologisk-eksperimentell artikkel (van Dijk 1980: 120)). Vi skal nå se nærmere på hvordan Adam forholder seg til Werlich og van Dijk og hvordan han presenterer sin egen typologiseringsmodell.

Jean-Michel Adam var, i sine tidlige arbeider om teksttypologi, sterkt inspirert av såvel Werlich som van Dijk, blant annet av deres lingvistiske utgangspunkt. I sin bok fra 1992 viser han imidlertid at han har distansert seg fra begge disses hovedhypoteser. Når det gjelder muligheten for å utvikle en teksttypologi basert på enkle basissetninger, etter Werlichs måte, avviser Adam dette ved å vise til at det er umulig ikke å ta i betraktning forholdet mellom lokale og globale dimensjoner 
når det gjelder et bestemt språklig fenomens funksjon i teksten. En enkel setning kan bare defineres som for eksempel narrativ eller argumentativ i lys av både grammatiske trekk og av den plassering den har i en kotekstuell sammenheng (Adam 1992: 39). Adam innrømmer at enkelte lingvistiske trekk i større eller mindre grad kan invitere til eller hindre en bestemt typologisk tolkning (op.cit.: 39), men sammenhengen de forekommer i er avgjørende. Han synes å avvise muligheten av å liste opp strengt definerte morfo-syntaktiske trekk som karakteristiske for en teksttype (se hans syn på dette i presentasjonen av den narrative sekvens (op.cit.: 71)).

Når det gjelder Adams syn på superstrukturbegrepet, avviser han $\mathrm{i}$ hovedsak også dette i 1992-boken. Han innrømmer å følge van Dijk til en viss grad (op.cit.: 32-33), men kan ikke godta hans begrep fordi det er for vagt og fordi det gjelder hele tekster. Et av Adams hovedpostulater, nemlig teksters heterogeneitet (se nedenfor), går ikke særlig godt sammen med van Dijks begrep om en superstruktur for hele tekster.

Adam gir klart uttrykk for at han kjenner til og aksepterer den skepsis som råder når det gjelder typologisering av hele tekster. Dette forhindrer ham imidlertid ikke i å formulere en mer restriktiv hypotese, nemlig en hypotese om noen få elementære sekvenstyper. I virkeligheten foretar Adam en redefinering av van Dijks tekstuelle superstrukturer til prototypiske skjemaer for mindre enheter enn teksten (op.cit.: 14). Dette kan han gjøre ved å skille skarpt mellom en tekstdimensjon og en sekvensdimensjon. Han støtter seg her på Bakhtins mer sosiolingvistiske diskurstilnærming, men understreker at han streber mot en klarere lingvistisk definert tekstualitet enn det Bakhtin gjør (op.cit.: 1314). Og selv om han innrømmer at sosiale genrekonvensjoner spiller en rolle i all verbal kommunikasjon, avviser han dette perspektivet for typologisering, ettersom disse konvensjonene ikke er strengt lingvistisk bestemt - de er multidisiplinære (Adam 1992: 15-17).

I sin typologiseringsmodell beveger Adam seg fra en teori om superstrukturer til en hypotese om teksters sekvensielle struktur og om eksistensen av visse prototypiske sekvensielle skjemaer. Sekvenstypene, i et antall av fem, er de følgende: narrativ, deskriptiv, argumentativ, eksplikativ og dialogisk. Det er en nær forbindelse mellom disse fem elementære typene og tekstuell heterogeneitet: En hel tekst kan bestå av en eller flere sekvenstyper i forskjellige relasjoner. 
Etter min mening synes Adams hovedprinsipper rimelige og lovende. Det finnes mange nok tekststudier til å underbygge hans syn på tekster som heterogene størrelser og på teksttypologier som for ambisiøse og urealistiske prosjekter. Enheten sekvens synes mer passende for typologisering. Likeledes er det ikke særlig problematisk å støtte ham i en avvisning av typesetninger som basis for en teksttypologi. Det er imidlertid grunn til å se nærmere på den lingvistiske forankring han mener å basere sin typologi på.

I sine tekststudier foretrekker Adam en modulær tilnærming hvor flere moduler må trekkes inn. Han definerer en tekst som en konfigurasjon som styres av forskjellige moduler eller undersystemer som er i konstant interaksjon med hverandre. Disse modulene er sentrert om følgende dimensjoner: 1) illokusjonær hensikt (visée illocutoire (cohérence)), 2) enonsiative spor (repérages énonciatifs), 3) semantisk kohesjon (cohésion sémantique (mondes)), 4) tekstuell sammenbinding (connexité textuelle) og 5) sekvensialitet (séquentialité) (op.cit.: 21). Av de fem modulene eller nivåene svarer de tre første til det han kaller den pragmatiske organisering (eller konfigurasjon) og de to siste åpner for en beskrivelse av tekst som en linjær suksesjon av proposisjoner.

Det er den sekvensielle modulen (modul 5) som er det viktigste studieobjektet i Adams bok, fordi den etter hans mening er den mest interessante i typologiseringssammenheng. Det synes, sier han, som om prototypiske sekvensielle skjemaer blir progressivt utviklet av språkbrukere i løpet av deres kognitive utvikling (op.cit.: 28). Selv om en sekvens blir betraktet som original, når den blir identifisert som en sekvens av en bestemt type, har den et visst antall lingvistiske helhetstrekk, (un air de famille), som inviterer leseren til å tolke den som mer eller mindre typisk, mer eller mindre kanonisk. Etter min mening er dette en fornuftig måte å studere teksttypologi på. Adam hevder at en slik oppfatning tillater studier av komposisjonell heterogeneitet i hierarkiske termer og i overensstemmelse med et enhetlig fundamentalt struktureringsprinsipp. Sekvensen, tekstens konstituerende størrelse, er selv sammensatt av makroproposisjoner. Disse er i sin tur sammensatt av proposisjoner. Følgende elementære hierarkiske struktur blir fremsatt som gyldig for alle tekster (op.cit.: 30):

\section{[ Tekst [Sekvens(er)[makroproposisjoner [proposisjon(er)]]]]}

Når det gjelder heterogeneiteten, et normal trekk ved tekster, skiller Adam mellom to tilfeller: 
1) Innføyning (insertion): forskjellige sekvenser alternerer i en relasjon av innføyende og innføyd, for eksempel når en deskriptiv sekvens er innføyd i en narrativ:

[narrativ [deskriptiv] narrativ].

2) Forskjellige sekvenser blandes i en relasjon dominerende/dominert: [narrativ > deskriptiv].

De ikke-sekvensielle modulene som Adam refererer til, får liten omtale, til tross for deres klare lingvistiske relevans. Selv om sekvensialiteteten er Adams studieobjekt i denne sammenheng, burde de andre modulenes rolle understrekes tydeligere. Etter min mening kan en større vektlegging av disse modulene komplettere den lingvistiske forankring $\mathrm{i}$ Adams modell.

I hovedsak finner jeg Adams påståtte lingvistiske forankring utilfredsstillende. Definisjon og avgrensning av de forskjellige kategorier (makroproposisjoner) som inngår i de enkelte sekvenser er ikke tilstrekkelig forankret i mulige og relevante språklige trekk. Min påstand er at polyfonien, som én av flere mulige faktorer, kan bidra betraktelig med en lingvistisk komplettering av Adams oppsatte protypiske sekvenser.

I denne artikkelen er det altså en polyfonisk tilnærming som skal vektlegges, et perspektiv som Adam så vidt nevner (op.cit.: 24) i forbindelse med presentasjonen av sin modul repérages énonciatifs ('enonsiative spor', utsigelsesmodul). Det Adam vektlegger i denne modulen er enonsiative markeringer i forhold til distinksjonen talt/skrevet tekst og til diverse genrer som ordtak, vitenskapelige fremstillinger og poesi. For det lokale plan, nevnes det faktum at ytringer kan tas ansvar for eller ikke av lokutøren. Det er i denne sammenheng polyfoni er nevnt (op.cit.: 24) uten å bli utnyttet videre. Nedenfor skal jeg presentere noen av polyfoniteoriens viktigste begreper.

\section{Lingvistisk polyfoni og teksttypologi}

For en fyldig gjennomgang av den lingvistiske versjonen av polyfoniteorien viser jeg til Henning Nølkes mange arbeider om emnet (særlig Nølke 1989 og 1994, se også Ducrot 1984). Her kan det ikke bli snakk om annet enn en meget kort og overfladisk gjennomgang. Jeg vil likevel minne om det som kanskje er polyfoniteoriens overordnede mål, nemlig å kontestere postulatet om at det talende subjekt er unikt eller udelelig. Troen på eller idéen om at en ytring har én og bare en avsender 
blir kraftig imøtegått. Det var med russeren Bakhtins litterære studier at det for alvor ble stilt spørsmål ved det talende subjekts unike karakter. Begreper som polyfoni og dialogisme skulle sprenge denne oppfatningen. Selve begrepet polyfoni, som egentlig ble innført av Bakhtins disipler og oversettere, skulle dekke det fenomen at flere stemmer kommer til uttrykk i en diskurs.

Polyfoni betraktet som flerstemmighet er imidlertid en svært vag karakteristikk, som tillater minst tre tolkninger:

1) Polyfoni kan for det første betegne at flere stemmer manifesterer seg i suksessive ytringer. Det er det ikke noe særlig revolusjonerende ved.

2) Den andre bruken av polyfoni har vi i det det spesielle tilfellet hvor man har stemmedualitet i ytringen. Det dreier seg om å gjenta og integrere mottakers stemme i ytringen. Denne form for polyfoni har Genèveskolen videreutviklet og gitt navnet diafoni (Roulet et al. 1985).

3) Endelig kan polyfoni forstås som en manifestering av flere stemmer i en og samme ytring. Det er denne bruken av begrepet som særlig Oswald Ducrot og i sin tur Henning Nølke har utviklet innenfor en lingvistisk ramme og som skal brukes her. Jeg skal i det nedenstående se på noen av de begreper og kategorier som inngår i denne teorien.

I et lingvistisk perspektiv er det viktig å avdekke hvordan ytringen selv signaliserer at flere synspunkt (stemmer) på en måte ligger oppå hverandre. For å lykkes i dette er det en første distinksjon som blir viktig å opprette, nemlig skillet mellom lokutфr (locuteur) og synspunkt (point de vue). Lokutøren, som er den instans pronomenet jeg refererer til, er ansvarlig for ytringen (ifølge ytringen selv), mens et synspunkt kan komme til uttrykk i en ytring uten at det tillegges bestemte ord (en semantisk størrelse). Ved hjelp av denne distinksjonen kan forskjellige lingvistiske fenomener beskrives innenfor en polyfonisk ramme. Den syntaktiske nekting er blitt det klassiske eksemplet, som i Ducrots mye brukte eksempel Ce murn'est pas blanc. I norsk versjon kan dette analyseres som følger (sp står for synspunkt):

(1) Denne veggen er ikke hvit. sp1 'Denne veggen er hvit' sp2 'sp1 er ikke sant'.

Her introduserer lokutøren, som er ansvarlig for ytringen, et synspunkt sp1 som sier at 'Denne veggen er hvit' og et annet synspunkt sp2 som 
lokutøren identifiserer seg med og som sier at sp1 ikke er sant. Når lokutøren benytter seg av nekting kan det være fordi andre har sagt eller trodd eller kunne tro at 'Denne veggen er hvit', og det synspunktet går imot lokutørens oppfatning (jeg går ikke inn på skillet deskriptiv/polemisk nekting her, se Fløttum under utgivelse b). Vi kan merke oss at synspunkt 2 nødvendigvis må være lokutørens, i alle fall hvis det dreier seg om koherent diskurs, mens det ut fra ytringen alene ikke er mulig å si hvem som er ansvarlig for det første. Identifisering av de som er ansvarlige for de forskjellige presenterte synspunkt blir en viktig del av teksttolkningen.

Slik nektingseksemplet viser tillater polyfoniteorien å formalisere mer eller mindre intuitive antagelser man kan ha om flerstemmighet. Dette gjør det mulig å eksplisitere en lang rekke relasjoner mellom en ytrings form og dens mening.

I tillegg til lokutør må vi selvfølgelig ha med den størrelse som ytringen er eller kan være rettet mot, allokutфren (allocutaire). Blant sporene etter denne finner vi 2. personspronomen.

Jeg nevner også at både Ducrot og Nølke skiller mellom to typer lokutører, som har forskjellige diskursive egenskaper (se Nølke 1994). Disse er for det første le locuteur-en-tant-que-tel (lokutør-som-lokutør, 1), som er lokutør i kraft av å være ansvarlig for ytringen, men som kun eksisterer i selve utsigelsen av denne. Den andre er le locuteur-en-tantqu'individu (lokutør-som-individ, L), som i tillegg til å være lokutørsom-lokutør også har en eksistens uavhengig av utsigelsen og dermed også andre egenskaper enn å være ansvarlig for den aktuelle ytringen. Uten at jeg skal gå nærmere inn på dette her, illustrerer et eksempel som (2) dette skillet (direkte oversatt etter Nølkes eksempel Je me demande si...):

(2) Jeg spør meg selv om ...

Her forstår man intuitivt at de to tilfellene av 1. persons-pronomenet ikke henviser til samme størrelse. Mens Jeg henviser til lokutøren-somlokutør, så henviser meg til lokutøren-som-individ. Når jeg i det følgende bruker termen lokutør, mener jeg lokutør-som-lokutør (l), dersom ikke noe annet blir sagt (det er ikke alltid relevant å gjøre skillet).

I tillegg til lokutør, allokutфr og synspunkt har Nølke også innført termen diskursindivid (som Ducrot ikke har som formell størrelse). Diskursindividene er de størrelser som kan gjøres ansvarlige for syns- 
punktene som kommer til uttrykk. De kan i tillegg til lokutør eller allokutør være andre størrelser som er innført i diskursen eller som befinner seg andre steder i det aktuelle diskursuniverset.

Diskursindividene tjener til å forankre språket i den ekstralingvistiske virkelighet $\mathrm{i}$ den forstand at deres typiske funksjon er å henvise til fysiske ekstralingvistiske størrelser eller individer. Men det er her viktig å understreke at den lingvistiske polyfoniteorien ikke postulerer noen bestemt forbindelse mellom diskursindivid og fysisk, reelt individ. Når man oppretter slike forbindelser beveger man seg på tolkningsplanet.

Før jeg går videre til andre begreper, vil jeg nevne at en av lokutørensom-individs viktige funksjoner er å sikre en teksts koherens (se Fløttum under utgivelse a). Dersom man forestiller seg at hver setning i en tekst har sin egen lokutør-som-lokutør, kan man tenke på lokutørensom-individ som en størrelse som alle lokutører-som-lokutør er forskjellige bilder av, og slik dannes det sammenheng i teksten. I forhold til språklige virkemidler som tema-rema-struktur, anaforiske relasjoner, konnektorer og semantisk isotopi, som alle markerer koherens, har polyfoni vært lite studert. Polyfoni er imidlertid etter min mening svært relevant i denne sammenheng. Det er nemlig slik at leseren av en tekst vil forvente at den er polyfonisk koherent. Det bør være en viss sammenheng eller koherens mellom de mange ulike synspunkter som presenteres i en tekst. Noe av det mest interessante i en polyfonisk koherensanalyse vil være å finne ut hvordan de ulike synspunkter forholder seg til diskursindividene og å avsløre nettet av relasjoner mellom diskursindividene og de forskjellige synspunkter (for de forskjellige relasjonene, se nedenfor). Man vil blant annet stille seg spørsmålet om 1 er bilder av samme L. Ved slik å avdekke synspunkter og relasjoner etablerer man et eksplisitt utgangspunkt for tolkningsnivået, hvor man vil søke å identifisere diskursindividene, knytte dem til reelle størrelser, som avsender, mottaker, og andre, for å nå frem til tekstens helhetlige mening. Slike relasjoner vil muligens også kunne være en faktor i typologiseringssammenheng (mer om dette nedenfor).

Vi har sett at lokutøren (l) kan presentere flere synspunkter i en og samme ytring. Det blir da viktig å avdekke hvilke relasjoner lokutøren skaper mellom de forskjellige synspunkter, på den ene siden, og diskursindividene, seg selv inkludert, på den andre siden. Her opererer Nølke med tre relasjoner, som jeg selv også har brukt og funnet fruktbare i 
forskjellige sammenhenger, i tekstanalyse generelt (se Fløttum under utgivelse a og b) og i analyse av tekstresyméer (se Fløttum 1992).

Relasjonene som lokutøren kan etablere mellom seg selv og de synspunktene som han fremkaller, er de følgende:

1) Ansvarsrelasjon: Lokutøren presenterer seg som opprinnelsen til det aktuelle synspunkt og gjør det til sitt: Han assosierer seg eller identifiserer seg med synspunktet.

2) Enighetsrelasjon: Lokutøren presenterer seg som ikke-ansvarlig for synspunktet, men aksepterer det som sant eller begrunnet inntil videre. Slik kan han tillate seg å bygge videre på dette synspunktet senere $\mathrm{i}$ diskursen. Lokutøren er altså foreløpig enig i dette synspunktet uten å gjøre det til sitt.

3) Ikke-ansvarsrelasjon: Lokutøren presenterer seg som ikke-ansvarlig for synspunktet (og tar ikke stilling til dets validitet). Han forbeholder seg friheten til å gå imot det, ta avstand fra det. Faktisk er det som regel grunnen til at han presenterer et slikt synspunkt. Lokutøren assosierer seg altså ikke med dette synspunktet.

Som vi har sett i (1) er det fullt mulig for lokutøren å identifisere seg med et synspunkt (ansvarsrelasjonen) samtidig med at han tar avstand fra et annet i en og samme ytring (ikke-ansvarsrelasjonen). Det er den syntaktiske nektingen et utmerket eksempel på.

Et eksempel på enighetsrelasjonen har vi i (3), som kan analyseres polyfonisk på følgende måte:

(3) Selv om jeg er syk, reiser jeg til utlandet.

sp1 jeg er syk (p)

$\mathrm{sp} 2 \mathrm{p}$ er et argument for $\mathrm{r}(\mathrm{r}=$ være hjemme $)$

sp3 jeg reiser til utlandet

sp4 at p er et argument for $r$ er ikke sant

1 aksepterer sp1 (enighetsrelasjonen), tar avstand fra sp2

(ikke-ansvarsrelasjonen) og identifiserer seg med sp3 og sp4 (ansvarsrelasjonen)

Det er relasjonene mellom diskursindividet avsender og de iscenesatte synspunkt man gjerne ser etter først. Likevel er selvfølgelig også de andre diskursindividene viktige for tolkningen. De samlede relasjoner mellom diskursindivider og synspunkt utgjør en vesentlig del av en ytrings innhold. Avdekkingen av disse relasjonene eller båndene er viktig for å forstå ytringen og i sin tur teksten som ytringen er en del av. 
Jeg har i det ovenstående brukt nekting og innrømmelse som eksempler på polyfoni. Det finnes selvfølgelig mange andre. Noe av det mest interessante med polyfonibegrepet er nettopp at det er så vidtrekkende: Det kan brukes på svært mange språklige fenomen. Noen opplagte som kan nevnes her er, er konnektorer (se selv om i (3)), setningsadverbialer, gjengitt tale.

La oss nå se nærmere på den dimensjonen av tekstanalyse som er mest interessant innenfor rammen av denne artikkelen, nemlig den typologiske. Man kan etter min mening tenke seg en tekst- eller sekvenstypologi med polyfoni som en viktig faktor for å karakterisere forskjellige typer (se Fløttum under utgivelse a og b). Jeg tror polyfoniteorien kan utgjøre et viktig og interessant bidrag i denne sammenheng, kanskje særlig fordi den er så klart lingvistisk basert. Som vi har sett ovenfor har diskusjonen rundt teksttypologier i stor grad vært preget av skepsis på grunn av vanskene med å finne klart definerte lingvistiske kriterier som basis for en typeinndeling. Polyfoniteorien gir oss nettopp eksplisitte kriterier. Dessuten er det rimelig å anta at graden av polyfoni vil variere med type. Rent intuitivt vil argumentative tekster være sterkere polyfoniske enn f.eks. narrative. Kriteriene kunne være, blant andre, antall eller frekvens av synspunkter, antall og typer av manifeste diskursindivider (kriterier for å bestemme en tekstsekvens etter graden av polyfoni), og typer av relasjoner som kommer til uttrykk mellom synspunkter og diskursindivider (kriterium for å bestemme en tekstsekvens etter typer av polyfoniske relasjoner).

Nedenfor skal jeg ikke gå videre inn på det dristige spørsmålet om polyfonien faktisk kan være basis (det vil si hovedfaktoren) for en typologi. Det som er mitt mål her er kun å bruke polyfoniteorien som støtte til den språklige forankring i Adams etablerte sekvenstypologi.

\section{Prototypiske sekvenser $i$ et polyfonisk perspektiv}

Jeg skal gjengi et par eksempler som Adam presenterer som mer eller mindre typiske for to av de sekvenstyper han stiller opp, og se nærmere på i hvilken grad et polyfonisk perspektiv kan komplettere Adams analyse.

Det første eksemplet er et kanonisk eksempel på en narrativ sekvens etter Adams modell (bokstavene angir de forskjellige makroproposisjoner som Adam har inndelt sekvensen i): 
(a) L'IRA revendique l'attentat de Brighton : 4 morts et 30 blessés

(b) GOD SAVES MAGGIE

(c) Deux heures cinquante du matin, hier, dans la petite ville de Brighton, au sud de l'Angleterre. Au bar du Grand Hôtel, les derniers parlementaires Conservateurs se préparent à rejoindre leurs chambres. Margaret Thatcher, dans son cabinet de travail, met un point final au discours de clôture du congrès annuel de son parti. L'hôtel est habité par la presque totalité des membres de son cabinet, des hommes politiques et des députés. (d) Soudain, c'est l'explosion. (e) L'Armée Républicaine Irlandaise avait posé une bombe au troisième étage. (f) Margaret Thatcher est vivante, mais quatre personnes sont tuées, trente autres blessées, dont un ministre et un député. (g) Après la stupeur, fidèle à son image, le ler ministre britannique annonce que le congrès continue.

(Libération, 13-14/10-1984, gjengitt av Adam 1992: 73).

Sekvensen inneholder alle kategoriene eller makroproposisjonene som inngår i Adams protypiske narrative skjema: résumé (a), morale (b), situation initiale (c), complication (d), action/évaluation (e), résolution (f) og situation finale (g). Rekkefølgen på makroproposisjonene svarer også til den prototypiske bortsett fra makroproposisjonen morale, som ofte står til slutt i sekvensen. Adam angir makroproposisjonene uten å gå nærmere inn på en lingvistisk begrunnelse for analysen. Jeg vil derfor vise at et polyfonisk perspektiv kan styrke Adams foreslåtte analyse, som intuitivt virker rimelig.

Et opplagt polyfonisk fenomen i denne tekstsekvensen er konnektoren mais (se (f)), som angir en innrømmelsestruktur. Jeg skal ikke gjennomføre en formell polyfonisk analyse av denne i forbindelse med denne tekstsekvensen (se neste teksteksempel for en slik analyse), men kun si noe om dens sentrale plassering. Enkelt sagt angir mais at lokutøren er enig i det synspunkt som kommer til uttrykk i den foregående proposisjon, uten å ta et særlig ansvar for det. Det viktigste er imidlertid at mais angir at lokutøren identifiserer seg med og tar ansvar for det synspunkt som følger. I dette tilfellet dreier det seg om synspunktet som kommer til uttrykk i quatre personnes sont tuées, trente autres blessées (...). Dette er en del av makroproposisjonen résolution, som sammen med makroproposisjonen complication er antydet som de viktigste i det narrative skjema. Konnektøren mais understreker denne viktigheten, men den gjør mer. Den markerer som nevnt hvilken del eller hvilket 
synspunkt i makroproposisjonen som er viktigst for lokutøren (hvilket han identifiserer seg med), nemlig at fire personer er døde og tredve såret. Viktigheten i den relasjonen mellom de to synspunkt som er angitt her, kommer også til uttrykk ved den klare forbindelsen til de makroproposisjonene Adam bestemmer som résumé og som morale: henholdsvis tittelen (L'IRA revendique l'attentat de Brighton : 4 morts et 30 blessés) og undertittelen (God saves Maggie). Til undertittelen (morale) svarer det synspunkt i résolution som lokutøren sier seg enig $\mathrm{i}$, uten å angi noen som helst ansvarsrelasjon (nemlig at Margareth Thatcher er i live). Kanskje ser vi også noe ironisk i denne undertittelen, særlig hvis den skal forstås som morale?

Vi kan likeledes merke oss at kategorien morale er plassert foran selve teksten, og ikke til slutt, slik det gjerne er i de mest typiske realisasjonene av den narrative sekvens. Til tittelen (eller rettere sagt til den delen som refererer til antall døde og sårede), bestemt som résumé og dermed den kategorien som gjerne inneholder artikkelens viktigste informasjon, svarer så det synspunkt i résolution som lokutøren identifiserer seg med og tar ansvar for (nemlig at 4 er drept og 30 såret).

Oppsummerende kan vi si at den polyfoniske konnektøren mais bidrar med en lingvistisk eksplisitt - og i dette tilfellet helhetlig - forankring til den analyse i makroproposisjonelle kategorier som er foreslått av Adam.

I et annet eksempel på en narrativ sekvens, et utdrag av Prinsessen på erten (op.cit.: 32), sier da også Adam at argumentative konnektorer understreker sekvensens makroproposisjoner: Argumentatsjonen understreker tekstens organisering. Det kunne være like pertinent å si at det er den polyfoniske strukturen som eksplisiterer og understreker tekstens organisering. Den støtter lingvistisk den tolkning av makroproposisjoner som er foreslått.

I det neste eksemplet som skal studeres her, dreier det seg om et av Adams eksempler på argumentativ sekvens. Det er et utdrag av en tale om "det gode valg for Frankrike", holdt av president Valéry Giscard d'Estaing i 1978 (se Adam 1992: 27). Markeringen med bokstaver er gjort for lettere å kunne henvise til de mindre passasjer i sekvensen:

(a) Chacune de ces questions comporte une réponse claire. (b) Je n'ai pas à vous la dicter (c) car nous sommes un pays de liberté, (d) mais je ne veux pas non plus que personne, je dis bien personne, ne puisse dire un jour qu'il aura été trompé. 
I Adams prototypiske argumentative skjema inngår følgende kategorier eller makroproposisjoner: thèse antérieure (gammel tese), données (fakta), inférences (inferenser eller argumenter, som kan underbygges med garant og support), restriction (restriksjon) og endelig conclusion (konklusjon eller ny tese).

I motsetning til den narrative sekvensen studert ovenfor, er denne mye mer kompleks i sin oppbygning. Adam tolker i første omgang (b) og (c) som en regressiv argumentasjon med (b) (Je n'ai pas à vous la dicter) som konklusjon og (c) (car nous sommes un pays de liberté) som faktum. Denne lesningen revurderes når han kommer til (d), innledet med konnektoren mais (mais je ne veux pas non plus que personne, je dis bien personne, ne puisse dire un jour qu'il aura été trompé), som Adam leser som en restriksjon og som leder mot en ny implisitt konklusjon: J'ai à vous dicter votre réponse (som tilsvarer den positive varianten av (b), som først ble lest som konklusjon). Når det gjelder denne tolkningen nevner Adam eksplisitt det polifoniske perspektivs relevans. Han sier at man må forestille seg to proposisjoner i Je n'ai pas à vous la dicter (op.cit.: 24), en som "presidentlokutøren" tar ansvar for (den benektede) og en som Adam forklarer opprinnelsen til ved å gå bakover i talen hvor presidenten har fortalt om en hendelse fra krigen hvor han opplevde soldater som ropte Nous avons été trompés.

Til tross for at dette utdraget er svært «polyfont» og innbyr til polyfonisk analyse, utnytter Adam desverre ikke det til å forankre lingvistisk sin tolkning, som forøvrig virker intuitivt holdbar. Det er dette jeg vil prøve å gjøre ved en forenklet polyfonianalyse. Jeg forenkler ved blant annet å redusere (d) til det følgende: mais je ne veux pas non plus que $p$, og ved å utelate (a), som representerer en innledning til selve argumentasjon og som ikke har innflytelse på helhetstolkningen. Vi ser på analysen av de enkelte delene:

(b) Je n'ai pas à vous la dicter

sp 1: j'ai à vous la dicter

sp 2: sp 1 er ikke sant

- lokutør I avviser sp1 og identifiserer seg med sp2

(c) car nous sommes un pays de liberté

sp 3: hvorfor skal jeg tro på (b)?

sp 4: fordi 'nous sommes un pays de liberté'

- lokutør II avviser sp 3 og identifiserer seg med sp 4 
Passasjen (d) analyseres i to etapper,

først selve proposisjonen uten konnektoren mais :

je ne veux pas non plus que $\mathrm{p}$

sp 5: je veux que $\mathrm{p}$

sp 6: sp 5 er ikke sant

- lokutør III avviser sp 5 og identifiserer seg med sp 6

så innrømmelseskonstruksjonen som konnektoren mais inngår i:

$\mathrm{X}$ MAIS $\mathrm{Y}(\mathrm{X}=(\mathrm{b})+(\mathrm{c}), \mathrm{Y}=(\mathrm{d})$ uten mais $)$

sp 7: je n'ai pas à vous la dicter car nous sommes un pays de liberté $(\mathrm{X})$

sp 8: $\mathrm{X}$ er et argument for $\mathrm{r}$ (en konklusjon som må presiseres $\mathrm{i}$ tolkningen)

sp 9: je ne veux pas non plus que $\mathrm{p}(\mathrm{Y})$

sp10: $\mathrm{X}$ er ikke et argument for $\mathrm{r}$

- lokutør IV godtar eller er enig i sp 7, tar avstand fra sp 8 og identifiserer seg med sp 9 og sp 10.

Det viktige $\mathrm{i}$ helhetsanalysen er at $\mathrm{sp} 7$ godtas inntil videre (je n'ai pas à vous la dicter...), og dermed eksplisiterer at en mulig konklusjon kan trekkes på et foreløpig stadium i tolkningen, slik Adam gjør. Men like viktig er det at denne polyfoniske analysen ekplisiterer et synspunkt som Adam i sin analyse antyder som en ny, men implisitt konklusjon, nemlig sp1: j'ai à vous la dicter. Oppsummerende kan vi si at den mais som er brukt her, angir eksplisitt en restriksjon (je ne veux pas non plus $q u e p$ ). Denne er viktigere enn det som tidligere er uttrykt (fordi lokutøren identifiserer seg med den i en ansvarsrelasjon), og den styrer derfor mot en ny konklusjon, som polyfonianalysen faktisk allerede har ekplisitert i sp1.

\section{Konklusjon: polyfoni beskriver og forklarer teksttypo- logiske trekk}

I denne konklusjonen skal jeg ikke gi et klart svar på spørsmålet som ble formulert i innledningen, om muligheten av å bestemme en tekst som et eksempel på en type, ved hjelp av bestemte lingvistiske kriterier. Det jeg imidlertid vil konkludere med er at det finnes lingvistiske fenomener som i mye større grad enn hva tilfelle er, kunne bli utnyttet til å forankre teksttypologier språklig. I denne artikkelen har jeg gitt et par eksempler på at polyfoni er et slikt fenomen. 
Etter min mening representerer Adams inndeling i fem elementære sekvenstyper (hvorav to er nevnt i det ovenstående) et fornuftig og velbegrunnet utgangspunkt for typologisering. Det er imidlertid synd han ikke har utnyttet i større grad det potensiale som ligger i hans fem oppstilte moduler. Jeg har forsøkt å vise at polyfonien (som del av Adams modul 2) kan utnyttes i så måte.

For det første byr en polyfonisk tilnærming på et metodologisk fortrinn ved at den er vidtrekkende: Det er mange språklige fenomener som kan beskrives polyfonisk. Det er en tilnærming som kan brukes på alle typene sekvenser (om enn bare to er nevnt her). Det er kanskje vanskelig å si at en tekstsekvens kan karakteriseres på en tilfredssstillende måte alene ved hjelp av polyfoniske termer. Men ikke desto mindre kan polyfoniteorien såvel bidra både til en beskrivelse av tekstsekvenser som til en lingvistisk forklaring av de kategorier Adam opererer med. Polyfonianalysen beskriver synspunkter og relasjoner som kommer til uttrykk i sekvensen og den forklarer kompleksiteten i strukturene.

En polyfonisk analyse kan også forene setnings- og tekstperspektivet. Dette er særdeles viktig i forhold til tekstens koherens. Og de forskjellige måter koherens skapes på er av stor betydning for en teksttypologi.

En polyfonisk analyse fremskaffer altså en lingvistisk basis for tolkning. Det er en stor fordel med denne analysen at den er etterprøvbar på grunn av sin formelle forankring. Polyfoni er et attraktivt begrep som har hatt en tendens til å bli brukt på en relativt lite stringent måte. $\AA$ bruke begrepet på en systematisk og etterprøvbar måte forhindrer ikke overensstemmelse med intuisjonen!

\section{Referanser}

Adam, J.-M. (1992): Les textes : types et prototypes. Paris: Nathan.

Bhatia, V.K. (1993): Analysing Genre: Language Use in Professional Settings. London/ New York: Longman.

Ducrot, O. (1984) : Le dire et le dit. Paris: Minuit.

Fløttum, K. (1992): Polyphonic structure. In: A.-C. Lindeberg et al. (eds): Nordic Research on Text and Discourse. Abo Academy Press, 161-172.

Fløttum, K. (under utgivelse a): Cohérence textuelle et polyphonie. Actes du XVIe Congrès International des Linguistes (Paris 1997). Blir utgitt på CD-ROM, 1998, Elsevier. 
Fløttum, K. (under utgivelse b): Le Mot du P.D.G. - descriptif ou polémique?. In Y. Gambier (éd.): Discours professionnels en français. Berne: P. Lang.

Fløttum, K. (under utgivelse c): The Editorial - a heterogeneous genre. Proceedings from the 11 European Symposium on Language for Special Purposes (København 1997).

Frandsen, F. (1995): Kategoriseringsmodeller, typer av kriterier og gyldighetsområder. Netvark LSP-SSP Nyhedsbrev 10 (31-42).

Johansen, W. (1995): Tekstgenrer og virksomhedskommunikation. Netvark LSP-SSP Nyhedsbrev 10 (20-30).

Nølke, H. (1989): POLYFONI. En sprogteoretisk indføring. ARK 48. København: Handelshøjskolen i København.

Nølke, H. (1994): Linguistique modulaire : de la forme au sens. Louvain : Peeters.

Roulet, E. et al. (1985): L'articulation du discours en français contemporain. Berne: P. Lang.

Swales, J. (1990): Genre Analysis - English in Academic and Research Settings. Cambridge: Cambridge University Press.

Van Dijk, T.A. (1980): Macrostructures. Hilsdale, N.J.: Lawrence Erlbaum Associates, Publ.

Werlich, E. (1976): A Text Grammar of English. Heidelberg: Quelle \& Meyer. 